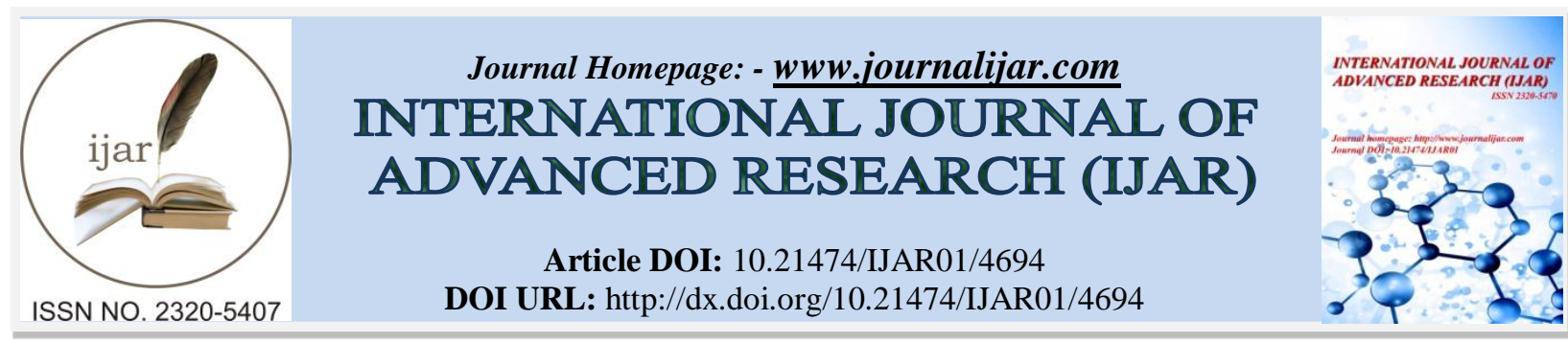

RESEARCH ARTICLE

\title{
THE EFFECT OF ANTERIOR MAXILLARY SEGMENTAL OSTEOTOMY ON FACIAL SOFT TISSUE
} PROFILE: A SYSTEMATIC REVIEW.

\section{Usama Hellal Bds Msd Ph.D ${ }^{1, *}$, Nabila Fayed Bds Msd Ph.D ${ }^{2}$, Rehab Elsharkawy Bds Msd Ph.D ${ }^{3}$ and Mostafa Abd Elrahmen Bds Msd Ph.D ${ }^{4}$.}

1. Postgraduate PhD Student, Department of Oral and Maxillofacial Surgery, Faculty of Oral and Dental Medicine Cairo University, Researcher Associate Orodental Genetic department, National Research Center

2. Professor of Oral and Maxillofacial Surgery, Faculty of Oral and Dental Medicine Cairo University

3. Associate Professor of Oral and Maxillofacial Surgery, Faculty of Oral and Dental Medicine Cairo University

4. Researcher of Orthodontic, Orodental Genetic department, National Research Center, 33 El Behooth St., Dokki, Giza, Egypt.

\section{Manuscript Info}

\section{Manuscript History}

Received: 1 May 2017

Final Accepted: 3 June 2017

Published: July 2017

Key words:-

Review, systematic, maxillary,

osteotomy; facial, profiles

\section{Abstract}

Introduction: Maxillary protrusion correction is usually by anterior maxillary segmental osteotomies. Evaluation of Changes occurring in facial soft tissues after anterior maxillary segmental osteotomy without mandibular surgery is needed. In this systematic review, we analyzed soft tissue changes and soft-to-hard tissue ratios regarding anterior maxillary segmental osteotomy.

Methods: electronic databases were used for collecting the articles that meet the inclusion and exclusion criteria and its references searched manually for additional relevant articles. The details and outcome data from each study were collected for comparison with each other using spreadsheets. The methodological quality of each study was assessed.

Results: three studies and two additional article were found in the reference that met the inclusion and exclusion criteria were collected. A reduction of the labial prominence with an increase in the nasolabial angle was noticed subsequent to anterior maxillary segmental osteotomies in all studies.

Conclusion: The magnitude of the reported soft tissue changes and their ratios corresponding to the osseous movements varied among studies. To predict the soft tissue changes in response to anterior maxillary segmental osteotomies, more prospective studies with sound methodology, larger samples and three dimensional evaluation are required with considering confounding factors such as age, sex, race and osteotomy technique.

Copy Right, IJAR, 2017,. All rights reserved.

\section{Introduction:-}

Systematic reviews are an important part of the evidence-based practice and decision-making process. Not only they summarize and clarify the existing data but also they allow to find the defect in our knowledge and helping us to identify what we need in future (Margaliot and Chung., 2007) .Systematic reviews allow focusing of available 
research on a specific topic and analysis of both the quality of undertaking research and the outcomes of the studies themselves. The outcomes of homogeneous studies can be merged in a meta-analysis regarding to sample characteristics, interventions, outcome measures and follow-up protocols, also it may highlight what further research would be helpful. Anterior maxillary segmental osteotomy (AMSO) is one of common surgical techniques using for maxillary protrusion correction with good stability and less amount of relapse. AMSOs can make changes in the facial profile, so the predictions of these changes are important for patient satisfactions. (Cohn-Stock., 1921) described the anterior segmental osteotomy of the maxilla for the first time, many modifications had been developed related to the surgical approaches and osteotomy designs (Wassmund., 1935,Wunderer., 1962 and Cupar., 1954)

The surgery carried out by extraction of one premolar on each side usually the first premolars, second premolars may be considered. Through the extraction site Vertical cuts are made and extent from buccal to palatal side. A horizontal bone cut is carried out at least $5 \mathrm{~mm}$ above the anterior tooth and canine apices to join the vertical cut on each side, then mobilized anterior segment can be altered in planned directions after sufficient bone removal. Once the proper positions of the anterior segment has been reached, it will be fixed in the new position by mean of fixations such as plates and screws or arch bars and wires. Assessment of the effect of AMSO on the facial profile is required to determine amount of hard tissue (HT) movement needed to make proper position of soft tissue (ST).

The results of studies that study the effect of AMSO on facial soft tissue without other surgery have not been analyzed systematically so the objective of this systematic review is to assess the effect of AMSO on facial soft tissue, also to know the relation of ST to HT movement results from AMSO.

\section{Materials and Methods:-}

\section{Key words formulation and databases Selection:-}

An electronic databases including PubMed and Cochrane Database of Systematic Reviews, Cochrane central register of controlled trials (CENTRAL) and Wily online library were searched in April 2017 without date or language restrictions using the key words and combinations of these used in the search included:

1. "Maxillary protrusion" or "Maxillary prognathism" or "Maxillary excess" or "Class II malocclusion" or "Dentoalveolar protrusion"

2. "Anterior segmental osteotomy" or "Anterior subapical osteotomy" or "Wunderer method" or "Wassmund method" or "Cupar method"

3. "Soft tissue" or "profile" or "morphology"

4. "\#1" and "\#2" and "\#3"

Most popular oral and maxillofacial surgery-related journals were manual searched also, including the International Journal of Oral and Maxillofacial Surgery, Journal of Cranio-Maxillofacial Surgery, British Journal of Oral and Maxillofacial Surgery, Oral Surgery Oral Medicine Oral Pathology Oral Radiology and Endodontology, Journal of Cranio-facial Surgery, and Journal of Maxillofacial and Oral Surgery, also the reference lists of the studies identified were also scanned for possible additional studies. The citations retrieved from each database were exported to the Mendeley bibliographic management free software (version 1.15.3 @2008-2015 Mendeley L TD). Duplicates were discarded. Hard copies of all relevant articles were retrieved after screening the titles and abstracts of each one and assessed for its eligibility by two authors independently (Hellal\&El-Sharkawy). Inclusion criteria and exclusion criteria were determined and all articles were independently assessed against this criteria. Disagreements concerning the selected studies were resolved by discussion.

Inclusion criteria were clinical studies with human subjects including randomized controlled trials (RCTs) controlled clinical trials (CCTs), non randomized clinical trials and retrospective studies a with the aim of assessed Quantifiable changes in the facial appearance using any imaging method following anterior maxillary segmental osteotomy performed alone without other jaw surgery.

\section{The exclusion Criteria were:-}

1. Review articles

2. Case reports

3. Studies using animal models or cadavers and those focusing on cleft, trauma or syndromic patients.

4. Anterior maxillary segmental osteotomy performed with concomitant mandibular surgery such as subapical alveolar osteotomies or bilateral sagittal split osteotomy or genioplasty were excluded. 


\section{Data collection and Fabrication of data extraction Form:-}

The study details and outcome data related to AMSO were collected using a prefabricated extraction form. The following data were extracted from the studies included in the final analysis: year of publication, number of patients, patient age range, race, type of surgical intervention, methods of fixation, follow-up period, imaging methods, methods of soft tissue analysis and ratio of hared tissue to soft tissue. Each study was checked with a quality assessment checklist based on a tool for assessing risk of bias in non-randomized studies of interventions (ROBINS) by (Sterne et al., 2016 ), in order to differentiate the strength of scientific evidence in clinical decision-making. Seven domain were used to determine the risk of potential bias for each study including the following: confounding, selection of participants into the study, classification of interventions, deviations from intended interventions, missing data, measurement of outcomes and selection of the reported result. The study was classified as having a low, moderate, serious and critical risk of bias according to the following criteria, if the study is judged to be at low risk of bias for all domains so it's considered low risk of bias, if the study is judged to be at low or moderate risk of bias for all domains so it's considered moderate risk of bias, if the study is judged to be at serious risk of bias in at least one domain, but not at critical risk of bias in any domain so it's considered serious risk of bias and if the study is judged to be at critical risk of bias in at least one domain so it's considered critical risk of bias. Data extraction and quality appraisal were performed. All data were entered into Excel spreadsheets for comparison.

\section{Results:-}

Only five studies (Ayoub et al., 1990, Pan et al., 1997, Okudaira et al., 2008, Shawky et al., 2012 and Diaf., 2013) were included for this review that met the inclusion and exclusion criteria. The sequence of selecting studies and the number of articles remaining at each stage is illustrated in Fig.1.

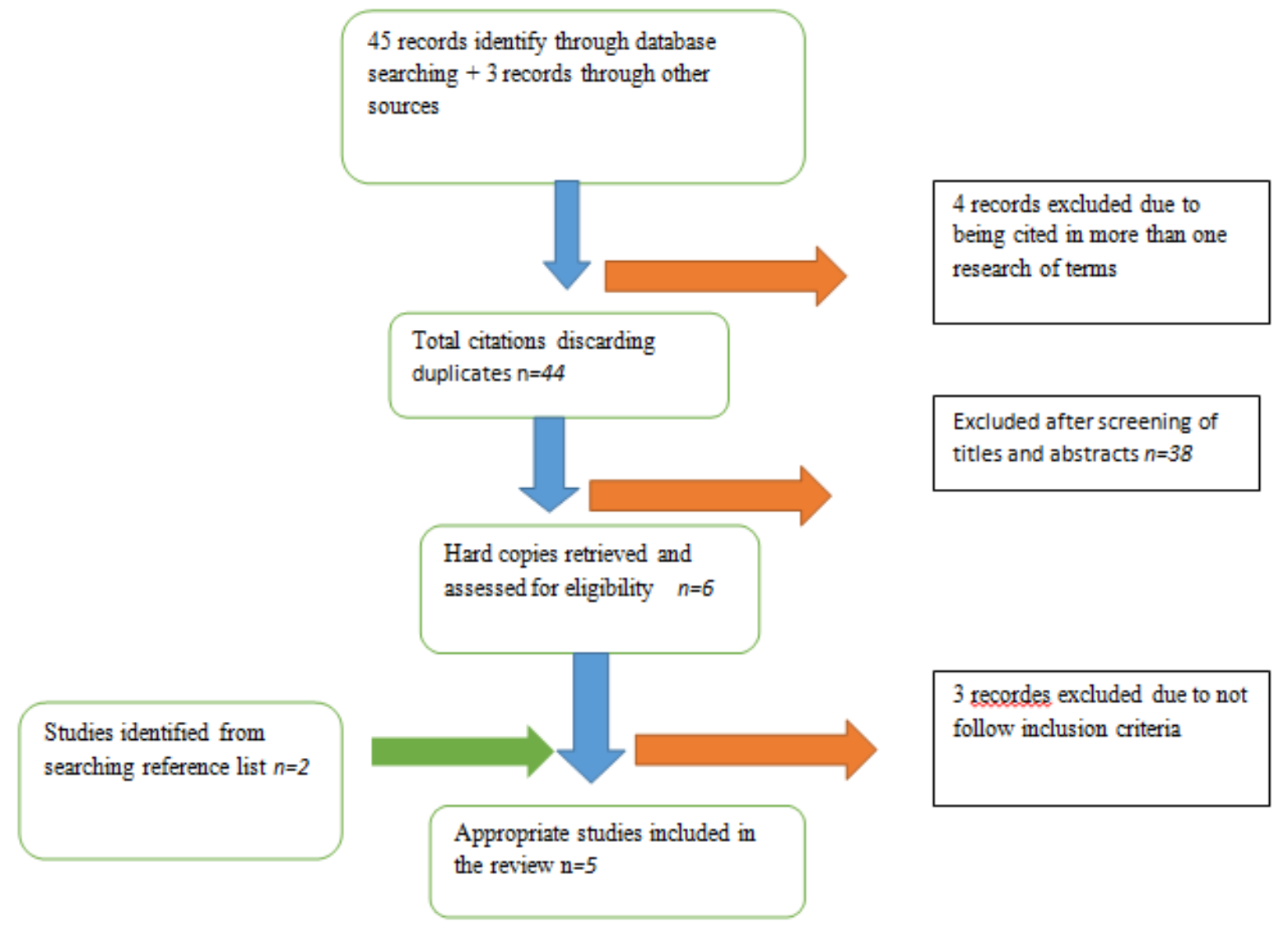

Fig 1:- A flow chart of the study selection process.

\section{Demographic data from the selected Studies:-}

All articles were published in English except a single Chinese article (Pan et al., 1997) (Table1). The study samples were heterogeneous and had different ethnicities and age groups, $40 \%$ of publications originated from the Asian 
region and $60 \%$ originated from the Caucasian region. 65 patients underwent AMSO without concomitant mandibular surgery. $75 \%$ of these patients were females and $25 \%$ were males. The patients aged 17-53 years.

Table 1:- Extraction data from the selected studies

\begin{tabular}{|l|l|l|l|l|l|l|l|}
\hline Authors (year) & $\begin{array}{l}\text { Count } \\
\text { ry }\end{array}$ & Race & Males & Females & Total & $\begin{array}{l}\text { Mean age } \\
\text { (years) }\end{array}$ & $\begin{array}{l}\text { Age range( } \\
\text { years) }\end{array}$ \\
\hline AYOUB et al. (1991) & UK & Caucassion & 2 & 8 & 10 & NR* & $17-23$ \\
\hline Okudaira et al. (2008) & Japan & Asian & 7 & 13 & 20 & 29.1 & $17.9-53.3$ \\
\hline PAN et al. (1997) & China & Asian & 5 & 10 & 15 & NR & $20-30$ \\
\hline Shawky et al.(2012) & Egypt & Caucassion & 0 & 6 & 6 & NR & $17-35$ \\
\hline Emad T. Daif (2013) & Egypt & Caucassion & 2 & 12 & 14 & 32 & $25-42$ \\
\hline
\end{tabular}

$* \mathrm{NR}$, not reported

\section{Surgical interventions and fixation methods:-}

Maxillary protrusion was the most common diagnosis. Wassmud and Wundere surgical techniques were used in three studies.(Ayoub et al., 1990' Okudaira et al., 2008, and Daf., 2013) but modified down fracture technique (Epker technique) used by (Shawky et al., 2012) one study (Pan et al., 1997) not reported surgical technique used for AMSO (Table 2). Stabilization or fixation methods don't discuss in details. Maxillary- mandibular fixation by arch bar and dental weir was used in two studies (Ayoub et al., 1990 and Daif..2013)while plates were used in two studies(Okudaira et al., 2008 and Shawky et al., 2012) four studies (Ayoub et al., 1990' Pan et al., 1997' Okudaira et al., 2008 and Daif., 2013) reported that all or some of the patients did orthodontic treatment.

Table 2:- Summary of the surgical interventions carried out in different studies

\begin{tabular}{|c|c|c|c|c|c|c|c|c|}
\hline $\begin{array}{l}\text { Author } \\
\text { s (year) }\end{array}$ & $\begin{array}{c}\text { Type of } \\
\text { deformity }\end{array}$ & $\begin{array}{l}\text { Maxillary } \\
\text { surgery }\end{array}$ & $\begin{array}{c}\text { Inter } \\
\text { maxill } \\
\text {-ary } \\
\text { fixatio } \\
\text { n }\end{array}$ & $\begin{array}{c}\text { Spl } \\
\text {-int }\end{array}$ & $\begin{array}{l}\text { Fixation } \\
\text { Method }\end{array}$ & $\begin{array}{l}\text { V-Y } \\
\text { Lip } \\
\text { clos } \\
\text { ure }\end{array}$ & $\begin{array}{l}\text { Pre/postsur } \\
\text { gical } \\
\text { Orthod- } \\
\text { ontics }\end{array}$ & $\begin{array}{l}\text { Other } \\
\text { special } \\
\text { Proced } \\
\text {-ures }\end{array}$ \\
\hline $\begin{array}{l}\text { AYOU } \\
\text { B et al. } \\
\text { (1991) }\end{array}$ & $\begin{array}{l}\text { Anterior } \\
\text { maxillary } \\
\text { excess }\end{array}$ & $\begin{array}{c}\text { Anterior } \\
\text { maxillary } \\
\text { Osteotomy } \\
\text { Wunderer } \\
\text { and Wassmund } \\
\end{array}$ & NR & NR & $\begin{array}{l}\text { maxillary- } \\
\text { mandibular } \\
\text { fixation }\end{array}$ & NR & yes & NR \\
\hline $\begin{array}{l}\text { Okudair } \\
\text { a et al. } \\
\text { (2008) }\end{array}$ & $\begin{array}{l}\text { maxillary } \\
\text { protrusion }\end{array}$ & $\begin{array}{c}\text { Anterior } \\
\text { maxillary } \\
\text { osteotomy with } \\
\text { modified } \\
\text { technique } \\
\text { based on } \\
\text { Wunderer } \\
\text { and Wassmund }\end{array}$ & NR & NR & Plate & NR & yes & NR \\
\hline $\begin{array}{l}\text { PAN et } \\
\text { al. } \\
(1997)\end{array}$ & $\begin{array}{l}\text { Anterior } \\
\text { maxillary } \\
\text { protrusion }\end{array}$ & $\begin{array}{l}\text { anterior maxillary } \\
\text { osteotomy }\end{array}$ & NR & NR & NR & NR & yes & None \\
\hline $\begin{array}{c}\text { Shawky } \\
\text { et } \\
\text { al. }(2012 \\
\text { ) }\end{array}$ & $\begin{array}{c}\text { excess of the } \\
\text { anterior part of } \\
\text { the } \\
\text { maxilla and } \\
\text { dental } \\
\text { protrusion with } \\
\text { a class I } \\
\text { occlusal relatio }\end{array}$ & $\begin{array}{l}\text { anterior segmental } \\
\text { maxillary } \\
\text { osteotomy } \\
\text { modified } \\
\text { downfracture } \\
\text { approach (Epker) }\end{array}$ & $\begin{array}{l}\text { tempor } \\
\text { ary } \\
\text { maxill } \\
\text { omand } \\
\text { ibular } \\
\text { fixatio } \\
\text { n }\end{array}$ & NR & $\begin{array}{c}\text { L-shaped } 2.0 \\
\text { titanium } \\
\text { miniplates }\end{array}$ & Yes & NR & NR \\
\hline $\begin{array}{l}\text { Emad } \\
\text { T. Daif } \\
\text { (2013) }\end{array}$ & $\begin{array}{l}\text { severe } \\
\text { maxillary } \\
\text { protrusion }\end{array}$ & $\begin{array}{l}\text { Anterior } \\
\text { maxillary } \\
\text { osteotomy }\end{array}$ & $\begin{array}{c}\text { maxill } \\
\text { ary- } \\
\text { mandi }\end{array}$ & NR & $\begin{array}{c}\text { arch bar, } \\
\text { dental wiring, } \\
\text { and a }\end{array}$ & NR & yes & None \\
\hline
\end{tabular}




\begin{tabular}{|c|c|c|c|c|c|l|l|}
\hline & Wunderer & $\begin{array}{c}\text { bular } \\
\text { fixatio } \\
\mathrm{n}\end{array}$ & $\begin{array}{c}\text { maxillary- } \\
\text { mandibular } \\
\text { fixation }\end{array}$ & & \\
\hline
\end{tabular}

NR, not reported

Imaging methods and techniques used for the Analysis:-

Lateral cephalometry were used by most studies for evaluation of ST changes (Table 3). (Shawky et al., 2012) used cone-beam computed tomography (CBCT) for 3D evaluation of ST. The presurgical imaging times were not reported in most studies except a single article (Okudaira et al., 2008) in which it was immediately before the surgery. The postsurgical imaging carried out more than 6 months after the surgical procedures in most studies. Tracing analysis was carried out manually by most authors, while some authors used digital tracing alone or with manual tracing (Ayoub et al., 1990 and Pan et al., 1997). The reference planes used for measurements were different between the studies. Only two studies (Ayoub et al., 1990 and Okudaira et al., 2008) used X line perpendicular to Y line at S (Sella). One study (Shawky et al., 2012) used H line perpendicular to V line at $\mathrm{N}$ (Nasion), other studies not reported reference lines (Pan et al., 1997) used sella as reference for registration of preand postsurgical images.

Table 3.:-Summary of the imaging methods and techniques used for the analysis

\begin{tabular}{|l|l|l|l|l|l|l|}
\hline $\begin{array}{l}\text { Authors } \\
\text { (year) }\end{array}$ & $\begin{array}{l}\text { Imaging } \\
\text { method }\end{array}$ & $\begin{array}{l}\text { Timing of } \\
\text { presurgical } \\
\text { imaging }\end{array}$ & $\begin{array}{l}\text { Timing of } \\
\text { postsurgi } \\
\text { cal } \\
\text { imaging }\end{array}$ & $\begin{array}{l}\text { Tracin } \\
\text { g } \\
\text { metho } \\
\text { d }\end{array}$ & $\begin{array}{l}\text { Reference } \\
\text { for registration } \\
\text { of pre- and } \\
\text { postsurgical } \\
\text { images }\end{array}$ & $\begin{array}{l}\text { Reference lines for } \\
\text { measurements }\end{array}$ \\
\hline $\begin{array}{l}\text { AYOUB } \\
\text { et al. } \\
\text { (1991) }\end{array}$ & $\begin{array}{l}\text { lateral } \\
\text { cephalog } \\
\text { rams }\end{array}$ & NR & $\begin{array}{l}\text { After } 6 \\
\text { months }\end{array}$ & H+D & NR & $\begin{array}{l}\text { X- Indiana line; } \\
\text { Y - perpendicular to } \\
\text { above at S }\end{array}$ \\
\hline $\begin{array}{l}\text { Okudaira } \\
\text { et al. } \\
(2008)\end{array}$ & $\begin{array}{l}\text { lateral } \\
\text { cephalog } \\
\text { rams }\end{array}$ & $\begin{array}{l}\text { immediately } \\
\text { before } \\
\text { surgery }\end{array}$ & $\begin{array}{l}\text { After 7 } \\
\text { months }\end{array}$ & H & NR & $\begin{array}{l}\text { X-parallel to } \\
\text { Frankfort plane } \\
\text { through S; Y - } \\
\text { perpendicular } \\
\text { to above at S }\end{array}$ \\
\hline $\begin{array}{l}\text { PAN et al. } \\
\text { (1997) }\end{array}$ & $\begin{array}{l}\text { Lateral } \\
\text { cephalog } \\
\text { rams }\end{array}$ & NR & $\begin{array}{l}8-24 \\
\text { months }\end{array}$ & H + D & Sella & $\begin{array}{l}\text { X-6.5 degrees to SN } \\
\text {; Y - NR }\end{array}$ \\
\hline $\begin{array}{l}\text { Shawky et } \\
\text { al.(2012) }\end{array}$ & CBCT & NR & $\begin{array}{l}\text { After 6 } \\
\text { months }\end{array}$ & D & NR & $\begin{array}{l}\text { H line- Frankfort } \\
\text { horizontal; } \\
\text { V line - } \\
\text { perpendicular to } \\
\text { above at N }\end{array}$ \\
\hline $\begin{array}{l}\text { Emad T. } \\
\text { Daif } \\
(2013)\end{array}$ & $\begin{array}{l}\text { lateral } \\
\text { cephalog } \\
\text { rams }\end{array}$ & NR & NR & H & NR & NR \\
\hline
\end{tabular}

NR, not reported; Lat.Ceph, lateral cephalogram; H, hand tracing; D, digitalization; S, sella turcica; N, nasion; X, horizontal reference plane; Y, vertical reference plane

\section{Quality Assessment:-}

The outcome of the quality assessment is shown in (Table 4). Each trial was assessed for risk of bias. Three studies were considered at moderate risk of bias (Ayoub et al., 1990, Okudaira et al., 2008 and Shawky et al., 2012) and two were considered at serious risk of bias (Pan et al., 1997 and Daif., 2013). The objective of the study was clearly formulated in all studies, but in some studies (Ayoub et al., 1990, Pan et al., 1997 and Shawky et al., 2012) well defined inclusion and exclusion criteria were lacked. The sample size was not adequate in all studies and the randomization in the Selection of subjects was not found in all studies. Data collection was not performed at consistent time frames in all the studies. Statistic data analysis and Follow up period reported in all studies but in 
most studies it was 6 or 7 months for postoperative imaging. No concurrent procedures in all studies. The metaanalysis was not performed Due to heterogeneous in studies in term of Race, participants, surgical procedure and methodology so their results cannot be extracted

Table 4:- The results of the quality assessment

\begin{tabular}{|c|c|c|c|c|c|}
\hline Bias assessment & $\begin{array}{l}\text { AYOUB } \\
\text { et al. } \\
\text { (1991) }\end{array}$ & $\begin{array}{l}\text { PAN et al. } \\
\text { (1997) }\end{array}$ & $\begin{array}{l}\text { Okudaira et } \\
\text { al. (2008) }\end{array}$ & $\begin{array}{l}\text { Shawky } \\
\text { et al. } \\
\text { (2012) }\end{array}$ & $\begin{array}{l}\text { Daif } \\
(2013)\end{array}$ \\
\hline $\begin{array}{l}\text { Bias due to confounding } \\
\text { - Is there potential for confounding of the } \\
\text { effect of intervention in this study? } \\
\text { - Risk of bias judgement }\end{array}$ & $\begin{array}{l}\mathrm{N} \\
\text { low }\end{array}$ & $\begin{array}{l}\mathrm{N} \\
\text { low }\end{array}$ & $\begin{array}{l}\mathrm{N} \\
\text { low }\end{array}$ & $\begin{array}{l}\mathrm{N} \\
\text { low }\end{array}$ & $\begin{array}{l}\mathrm{N} \\
\text { low }\end{array}$ \\
\hline $\begin{array}{l}\text { Bias in selection of participants into the } \\
\text { study } \\
\text {-Was selection of participants into the study } \\
\text { (or into the analysis) based on participant } \\
\text { characteristics observed after the start of } \\
\text { intervention? } \\
\text {-Do start of follow-up and start of intervention } \\
\text { coincide for most participants? } \\
\text {-Were adjustment techniques used that are } \\
\text { likely to correct for the presence of selection } \\
\text { biases? } \\
\text {-Risk of bias judgement }\end{array}$ & $\begin{array}{l}\mathrm{PN} \\
\mathrm{N} \\
\text { moderate }\end{array}$ & $\begin{array}{l}\mathrm{N} \\
\mathrm{PN} \\
\mathrm{N} \\
\text { Moderate }\end{array}$ & $\begin{array}{l}\mathrm{N} \\
\mathrm{N} \\
\text { moderate }\end{array}$ & $\begin{array}{l}\mathrm{N} \\
\mathrm{N} \\
\mathrm{N} \\
\text { moderate }\end{array}$ & $\begin{array}{l}\mathrm{N} \\
\mathrm{N} \\
\mathrm{N} \\
\text { Moderate }\end{array}$ \\
\hline $\begin{array}{l}\text { Bias in classification of interventions } \\
\text {-Were intervention groups clearly defined? } \\
\text {-Was the information used to define } \\
\text { intervention groups recorded at the start of the } \\
\text { intervention? } \\
\text {-Could classification of intervention status } \\
\text { have been affected by knowledge of the } \\
\text { outcome or risk of the outcome? } \\
\text {-Risk of bias judgement }\end{array}$ & $\begin{array}{l}\mathrm{Y} \\
\mathrm{PY}\end{array}$ & $\begin{array}{l}\text { PY } \\
\text { PY }\end{array}$ & $\begin{array}{l}\text { PN } \\
\text { low }\end{array}$ & $\begin{array}{l}\text { PN } \\
\text { low }\end{array}$ & $\begin{array}{l}\text { PN } \\
\text { low }\end{array}$ \\
\hline $\begin{array}{l}\text { Bias due to deviations from intended } \\
\text { interventions } \\
\text {-Were important co-interventions balanced } \\
\text { across intervention groups? } \\
\text {-Was the intervention implemented } \\
\text { successfully for most participants? } \\
\text {-Did study participants adhere to the assigned } \\
\text { intervention regimen? } \\
\text { Risk of bias judgement }\end{array}$ & $\begin{array}{l}\mathrm{Y} \\
\mathrm{Y} \\
\text { low }\end{array}$ & $\begin{array}{l}\mathrm{N} \\
\mathrm{PY} \\
\mathrm{PY} \\
\text { low }\end{array}$ & $\begin{array}{l}\mathrm{N} \\
\mathrm{Y} \\
\mathrm{Y} \\
\text { Low }\end{array}$ & $\begin{array}{l}\mathrm{N} \\
\mathrm{Y} \\
\mathrm{Y} \\
\text { low }\end{array}$ & $\begin{array}{l}\mathrm{N} \\
\mathrm{Y} \\
\mathrm{Y} \\
\text { low }\end{array}$ \\
\hline $\begin{array}{l}\text { Bias due to missing data } \\
\text {-Were outcome data available for all, or nearly } \\
\text { all, participants? } \\
\text {-Were participants excluded due to missing } \\
\text { data on intervention status? } \\
\text {-Were participants excluded due to missing } \\
\text { data on other variables needed for the } \\
\text { analysis? } \\
\text {-Is there evidence that results were robust to } \\
\text { the presence of missing data? }\end{array}$ & $\begin{array}{l}\mathrm{Y} \\
\mathrm{N}\end{array}$ & $\begin{array}{l}\mathrm{N} \\
\mathrm{N}\end{array}$ & $\begin{array}{l}\mathrm{Y} \\
\mathrm{N}\end{array}$ & $\mathrm{Y}$ & $\begin{array}{l}\mathrm{N} \\
\mathrm{N}\end{array}$ \\
\hline
\end{tabular}




\begin{tabular}{|c|c|c|c|c|c|}
\hline Risk of bias judgement & low & serious & low & low & serious \\
\hline $\begin{array}{l}\text { Bias in measurement of outcomes } \\
\text {-Could the outcome measure have been } \\
\text { influenced by knowledge of the intervention } \\
\text { received? } \\
\text {-Were outcome assessors aware of the } \\
\text { intervention received by study participants? } \\
\text {-Were the methods of outcome assessment } \\
\text { comparable across intervention groups? } \\
\text {-Were any systematic errors in measurement } \\
\text { of the outcome related to intervention } \\
\text { received? } \\
\text { Risk of bias judgement }\end{array}$ & $\begin{array}{l}\mathrm{N} \\
\mathrm{PY} \\
\mathrm{Y} \\
\mathrm{N} \\
\text { moderate }\end{array}$ & $\begin{array}{l}\text { PN } \\
\text { PY } \\
\text { Y } \\
\text { PN } \\
\text { moderate }\end{array}$ & $\begin{array}{l}\mathrm{N} \\
\mathrm{PY} \\
\mathrm{Y} \\
\mathrm{N} \\
\text { moderate }\end{array}$ & $\begin{array}{l}\mathrm{N} \\
\mathrm{Y} \\
\mathrm{Y} \\
\mathrm{N} \\
\text { moderate }\end{array}$ & $\begin{array}{l}\mathrm{N} \\
\mathrm{Y} \\
\mathrm{Y} \\
\mathrm{N} \\
\text { moderate }\end{array}$ \\
\hline $\begin{array}{l}\text { Bias in selection of the reported result } \\
\text { Is the reported effect estimate likely to be } \\
\text { selected, on the basis of the results, from... } \\
\text {... multiple outcome measurements within the } \\
\text { outcome domain? } \\
\text {... multiple analyses of the intervention- } \\
\text { outcome relationship? } \\
\text {...different subgroups? } \\
\text { Risk of bias judgement }\end{array}$ & $\begin{array}{l}\mathrm{N} \\
\mathrm{N} \\
\mathrm{N} \\
\text { low }\end{array}$ & $\begin{array}{l}\mathrm{N} \\
\mathrm{P} \\
\mathrm{N} \\
\text { low }\end{array}$ & $\begin{array}{l}\mathrm{N} \\
\mathrm{PN} \\
\mathrm{N} \\
\text { low }\end{array}$ & $\begin{array}{l}\mathrm{N} \\
\mathrm{N} \\
\mathrm{N} \\
\text { low }\end{array}$ & $\begin{array}{l}\mathrm{N} \\
\mathrm{N} \\
\mathrm{N} \\
\text { low }\end{array}$ \\
\hline $\begin{array}{l}\text { Overall bias } \\
\text { Risk of bias judgement }\end{array}$ & moderate & serious & moderate & moderate & serious \\
\hline
\end{tabular}

Y- Yes; PY- Probably yes; N- no; PN- Probably no

\section{Changes in Soft tissue profiles:-}

The mean horizontal and vertical movements of pronasale and subnasale were reported only by 2 studies (Ayoub et al., 1990 and Okudaira et al., 2008) (Table 5). There were less amount of movements for the pronasale. The subnasale was reduced $0.5 \mathrm{~mm}$ recorded by (Ayoub et al., 1990) also Okudaira et al., 2008) recorded $1.9 \mathrm{~mm}$ backward movement. The nasolabial angle increased with rang from 6.6 to 18.8 in all studies except study by (Okudaira et al., 2008). The labrale superius (Ls) was moved backward inferiorly with rang from $1.2 \mathrm{~mm}$ to $3.3 \mathrm{~mm}$, which indicated increased the length of the upper lip. labrale inferious(Li) not reported in most studies. Movement of Li upward was noted by (Ayoub et al., 1990) but (Okudaira et al., 2008) reported its movement in opposite direction. The upper lip in relation to the maxillary incisor displaced horizontally with ratios ranged from $50 \%$ to 75\% reported in most studies (Table 6). The horizontal displacement of the lower lip not reported in all studies. A reduction of the interlabial gap was reported in 2 studies (Ayoub et al., 1990 and Daif., 2013) ${ }^{\text {From }} 4.7-9 \mathrm{~mm}$. The upper lip thickness increased from 1.3 to $2.5 \mathrm{~mm}$ was noticed by (Ayoub et al., 1990) and Shawky et al., 2012).

Table 5:- The mean soft tissue movement's landmarks Table

\begin{tabular}{|c|c|c|c|c|c|c|c|c|c|c|c|c|c|c|c|}
\hline $\begin{array}{l}\text { Auth } \\
\text { ors } \\
\text { (year) }\end{array}$ & $\begin{array}{l}\text { Pn- } \\
\text { Hori } \\
\text { zont } \\
\text { al } \\
\text { Mea } \\
\text { n } \\
\text { (SD } \\
\text { ) }\end{array}$ & $\begin{array}{l}\text { Pn } \\
- \\
\text { Ve } \\
\text { rtic } \\
\text { al } \\
\text { Me } \\
\text { an } \\
\text { (S } \\
\text { D) }\end{array}$ & $\begin{array}{l}\text { Sn - } \\
\text { Hori } \\
\text { zont } \\
\text { al } \\
\text { Mea } \\
\text { n } \\
\text { (SD } \\
\text { ) }\end{array}$ & $\begin{array}{l}\text { Sn } \\
- \\
\text { Ve } \\
\text { rtic } \\
\text { al } \\
\text { Me } \\
\text { an } \\
\text { (S } \\
\text { D) }\end{array}$ & $\begin{array}{l}\text { Ls - } \\
\text { Hori } \\
\text { zont } \\
\text { al } \\
\text { Mea } \\
\text { n } \\
\text { (SD } \\
\text { ) }\end{array}$ & $\begin{array}{l}\text { Ls } \\
- \\
\mathrm{Ve} \\
\mathrm{rtic} \\
\text { al } \\
\mathrm{Me} \\
\text { an } \\
\text { (S } \\
\mathrm{D}) \\
\end{array}$ & $\begin{array}{l}\mathrm{Li}- \\
\text { Hori } \\
\text { zont } \\
\text { al } \\
\text { Mea } \\
\text { n } \\
(\mathrm{SD} \\
\text { ) }\end{array}$ & $\begin{array}{l}\mathrm{Li} \\
- \\
\mathrm{Ve} \\
\mathrm{rtic} \\
\text { al } \\
\mathrm{Me} \\
\text { an } \\
\text { (S } \\
\mathrm{D}) \\
\end{array}$ & $\begin{array}{l}\text { Labi } \\
\text { omen } \\
\text { tal } \\
\text { fold } \\
- \\
\text { Horiz } \\
\text { ontal } \\
\text { Mean } \\
\text { (SD) }\end{array}$ & $\begin{array}{l}\text { Labi } \\
\text { omen } \\
\text { tal } \\
\text { fold } \\
- \\
\text { Verti } \\
\text { cal } \\
\text { Mean } \\
\text { (SD) }\end{array}$ & $\begin{array}{l}\mathrm{Pg}- \\
\text { Hori } \\
\text { zont } \\
\text { al } \\
\text { Mea } \\
\mathrm{n} \\
\text { (SD } \\
{ }^{6}\end{array}$ & $\begin{array}{l}\mathrm{Pg} \\
- \\
\mathrm{Ve} \\
\mathrm{rtic} \\
\text { al } \\
\mathrm{Me} \\
\text { an } \\
\text { (S } \\
\text { D) }\end{array}$ & $\begin{array}{l}\text { Nas } \\
\text { olab } \\
\text { ial } \\
\text { angl } \\
\mathrm{e} \\
\text { Mea } \\
\mathrm{n} \\
\text { (SD } \\
\text { ) }\end{array}$ & $\begin{array}{l}\text { Ment } \\
\text { olabi } \\
\text { al } \\
\text { angle } \\
\text { Mea } \\
\mathrm{n} \\
\text { (SD) }\end{array}$ & $\begin{array}{l}\text { Other } \\
\text { releva } \\
\text { nt } \\
\text { measu } \\
\text { remen } \\
\text { ts }\end{array}$ \\
\hline $\begin{array}{l}\text { AYO } \\
\text { UB et } \\
\text { al. } \\
\text { (1991 } \\
\text { ) }\end{array}$ & +0.4 & 0 & -0.5 & 0 & -4.7 & $\begin{array}{l}- \\
2.4\end{array}$ & -1.1 & $\begin{array}{l}+2 . \\
6\end{array}$ & -1.2 & +0.5 & -0.7 & $\begin{array}{l}+0 . \\
2\end{array}$ & $\begin{array}{l}+18 \\
8\end{array}$ & $\overline{N R}$ & $\begin{array}{l}\text { SLS } \\
(\mathrm{H})= \\
1.8 ; \\
\text { SLS } \\
(\mathrm{V})=\end{array}$ \\
\hline
\end{tabular}




\begin{tabular}{|c|c|c|c|c|c|c|c|c|c|c|c|c|c|c|c|}
\hline & & & & & & & & & & & & & & & $\begin{array}{l}-1.6 ; \\
\text { Interl } \\
\text { abial } \\
\text { gap = } \\
4.7 \\
\text { mm; } \\
\text { Facial } \\
\text { conve } \\
\text { xity } \\
=- \\
1.38 ; \\
\text { Hold } \\
\text { way } \\
\text { angle } \\
= \\
4.88 ; \\
\text { H } \\
\text { angle } \\
= \\
5.48 ; \\
\text { Upper } \\
\text { lip } \\
\text { thickn } \\
\text { ess }= \\
+1.3 \\
\text { mm }\end{array}$ \\
\hline $\begin{array}{l}\text { PAN } \\
\text { et al. } \\
\text { (1997 } \\
\text { ) }\end{array}$ & NR & NR & NR & NR & NR & NR & NR & NR & NR & NR & NR & NR & $\begin{array}{l}+6.6 \\
(5.5)\end{array}$ & NR & $\begin{array}{l}\text { Stms } \\
- \\
\text { Stmi } \\
=\_4.7 \\
(3.7) ; \\
\text { Is }- \\
\text { Stms } \\
=\_2.0 \\
(2.0) ; \\
\text { Sn }- \\
\text { Stms } \\
= \\
+1.3 \\
(1.7)\end{array}$ \\
\hline $\begin{array}{l}\text { OKU } \\
\text { DAI } \\
\text { RA et } \\
\text { al. } \\
(2008 \\
)\end{array}$ & $\begin{array}{l}-0.2 \\
(0.6)\end{array}$ & $\begin{array}{l}0 \\
(0 . \\
2)\end{array}$ & $\begin{array}{l}-1.9 \\
(1.1)\end{array}$ & $\begin{array}{l}- \\
0.2 \\
(0 . \\
6)\end{array}$ & $\begin{array}{l}-3.6 \\
(1.8)\end{array}$ & $\begin{array}{l}- \\
1.2 \\
(1 . \\
2)\end{array}$ & $\begin{array}{l}-2.7 \\
(1.5)\end{array}$ & $\begin{array}{l}- \\
2.1 \\
(1 . \\
8)\end{array}$ & $\begin{array}{l}\mathrm{B}^{\prime}- \\
0.9 \\
(1.8)\end{array}$ & $\begin{array}{l}\text { B' }^{\prime} \\
0.9 \\
(1.8)\end{array}$ & $\begin{array}{l}-0.2 \\
\text { (1) }\end{array}$ & $\begin{array}{l}0(0 \\
.1)\end{array}$ & NR & NR & $\begin{array}{l}\mathrm{A}^{\prime}(\mathrm{H}) \\
=-3.3 \\
(1.3) ; \\
\mathrm{A}^{\prime}(\mathrm{V}) \\
=-0.7 \\
(1)\end{array}$ \\
\hline $\begin{array}{l}\text { Shaw } \\
\text { ky et } \\
\text { al.(20 } \\
12)\end{array}$ & NR & $\mathrm{NR}$ & NR & $\mathrm{NR}$ & $\begin{array}{l}- \\
0.6( \\
1.2)\end{array}$ & $\begin{array}{l}- \\
3.3 \\
(1)\end{array}$ & NR & NR & $\mathrm{NR}$ & NR & NR & NR & $\begin{array}{l}+18 . \\
7(0 . \\
8)\end{array}$ & NR & $\begin{array}{l}\text { lipthic } \\
\text { kness } \\
= \\
+2.5 \\
\mathrm{~mm} \\
\mathrm{IA}(\mathrm{V}) \\
=-6.2 \\
: \mathrm{IA}(\mathrm{H} \\
)=-0.3\end{array}$ \\
\hline
\end{tabular}




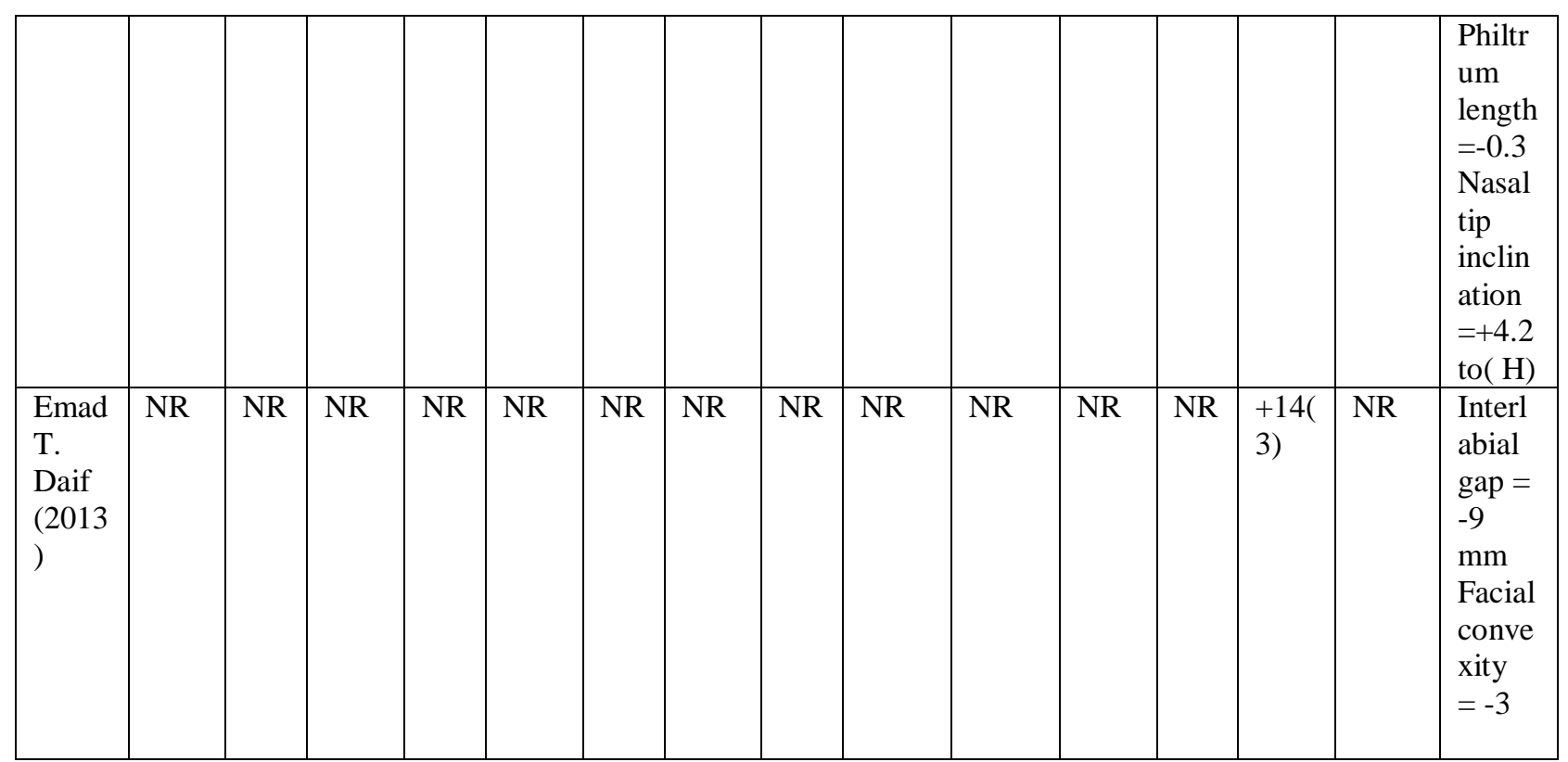

For landmark data, positive values indicate forward or upward movements and negative values indicate backward or downward movements in millimeters. For linear and angular measurements positive values indicate an increase and negative values indicate a reduction. A0, soft tissue A point; B0, soft tissue B point; Ls, labrale superius; Li, labrale inferious; Pg, pogonion; Pn, pronasale; NR, not reported; Sn, subnasale; Stms, stomion superious; Stmi, stomion inferious; SLS, superiorlabial sulcus;IA, incision anterius $\mathrm{H}$, horizontal; $\mathrm{V}$, vertical.

Table 6:- The hard and soft tissue movement Ratios.

\begin{tabular}{|c|c|c|}
\hline Authors (year) & Upper lip & Lower lip \\
\hline AYOUB et al. (1991) & Upper lip:upper incisor $=60 \%$ & NR \\
\hline Okudaira et al. (2008) & NR & NR \\
\hline PAN et al. (1997) & Is: Ls $=75 \%$ & NR \\
& A: A $^{0}=63 \%$ & NR \\
\hline Shawky et al.(2012) & $\begin{array}{c}\text { upper lip to the maxillary incisor } \\
\text { retraction was } 0.53: 1\end{array}$ & NR \\
\hline Emad T. Daif (2013) & NR & \\
\hline
\end{tabular}

$\mathrm{NR}$, not reported

A, hard tissue A point; A0, soft tissue A point; Is, incision superious; Ls, labrale superious.

\section{Discussion:-}

The sample size of the studies included in this systematic review was small this may be due to the prevalence of maxillary protrusion without concomitant mandibular deformity is less common. The increase in the ratio found in females more than males in all studies may be because females tend to improve facial appearance so they seek orthognathic surgery more than males (Bailey et al., 2000). In quality appraisal assessment there were several deficiencies in the study design. The selection of patients hadn't performed randomly or consecutively to avoid selection bias. There were difference in nomenclature of the cephalometric landmarks between studies, also the assessment of ST movements of all the potential landmarks were not performed in some studies. Only 3 studies (Ayoub et al., 1990, Okudaira et al., 2008 and Shawky et al., 2012) reported the HT: ST ratios (Table 6).

From our point of view due to the clinical and statistical significant difference of the upper labial component ratios these studies did not focus on lower labial landmarks, nasal and chin region, which lead to a defect in the available HT: ST ratios regarding the other soft tissue landmarks. The exact time of postsurgical imaging in most studies was from 6-7 month, but in the study of (Pan et al., 1997) it was 8-24 month. This may be to give period of time for postsurgical edema and hematoma to resolve and soft tissue to stabilize. Due to a shorter period of time in follow-up of patients in most studies there was a defect in information about long-term follow-up of ST response to AMSO. This point should be considered in future studies with longer periods of follow-up should be included in the study 
design. Data collection at constant time intervals should have been done with specified range of the articles. The differences in the follow-up cephalography records period may be an inherent error related to the retrospective study design.

Most studies didn't give details about the surgical techniques or methods of fixation. Different surgical techniques were used in the same study as in (Ayoub et al., 1990 and Okudaira et al., 2008). The effect of several surgical technique and its modifications with different methods of fixations on postoperative swelling and the final ST position was not possible to be evaluated. Many factors such as individual surgical skills, orthodontic treatment, thickness and elasticity of tissue and relapse can be affect the final ST also age, sex and race such variable factors may have a role in the postoperative ST position.

The labial prominence decreased subsequently to AMSO. Also the interlabial gap was reduced with good lip competence achieved by all patients (Table 5). Due to a reduction of the Ls there was an increase of the nasolabial angle with stable nasal landmarks. No studies reported if there any change in lower lip ST or The labiomental fold which can affect the facial profile.

Most studies used lateral cephalometry radiographs and photography for ST and HT assessment, (Shawky et al., 2012) used CBCT for 3D evaluation of ST, they reported that CBCT more accurate than traditional methods. The results of postoperative ST changes usually compared with preoperative records statistically by using the paired $\mathrm{t}$ test. A non-parametric t-test should be employed if the data don't follow a normal distribution. Exact p-value is recommended to be quoted rather than stating $\mathrm{p}>0.0534$. Wide variation of patient's ST response to AMSO was reported several studies as a result of the quite high standard deviations for ST landmarks (Table 5).

In order to add useful information for predicting the ST changes from AMSO, prospective clinical trials with larger samples with the same surgical technique and method of ST evaluation are required to consider the results of this systematic review. Protocols with good, sound methodology and follow-ups for a longer period of time are also needed. Most studies evaluate facial changes only in two dimensions, horizontal and vertical and not considering transverse facial changes so 3D imaging techniques should be considered in future studies in order to evaluate the HT and ST changes. In order to prevent bias during the evaluation of facial changes, the treatment providers should not directly involved in the assessment procedures

In this study, there was no restriction to only one database or to a certain language. A quality assessment checklist was used to assess the internal validity of each study (Table 4). Due to heterogeneity in the methodology and sample size used in this study, a meta-analysis cannot be done. Stimulating more and better researches are needed to be performed to demonstrate certainty in the present understanding, in addition to future researches are required based on certain data to avoid the drawbacks in this study knowing by this review.

In the light of the up mentioned limitation of literature size, quality and homogeneity we may conclude that AMSO reduces the upper lip prominence and the nasolabial angle increased. There were minimal changes in the chin and nasal landmarks but great ST changes were in the upper lip and nasolabial angle.

\section{Conclusion:-}

On Conclusions due to lack of good quality evidence, the amount of ST changes or ST to HT ratios cannot be assessed from this review so more clinical trials with sound methodology, larger samples and three dimensional evaluation are required with considering confounding factors such as age, sex, race and osteotomy technique, to give satisfied information for ST predictions in response to AMSO

\section{References:-}

1. Ayoub AF, Mostafa YA, El-Mofty S. (1990). Soft tissue response to anterior maxillary osteotomy. Int J Adult Orthodon Orthognath Surg.6 (3):183-90.

2. Bailey LJ, Haltiwanger LH, Blakey GH, Proffit WR. (2000). Who seeks surgical-orthodontic treatment: a current review. Int J Adult Orthodon Orthognath Surg.16(4):280-92.

3. Cohn-Stock G.(1921). Die chirurgische Immediatregulierung der Kiefer, speziell die chirurgische Behandlung der Prognathie. Vjschr Zahnheilk Berlin. 37:320.

4. Cupar I.(1954). Die chirurgische Behandlung der Form-und Stellungsveränderungen des Oberkiefers. Bull Soc 
Cons Acad RPF Jougosl. (51):565.

5. Daif ET.(2013). Soft-Tissue Profile Changes Associated With Anterior Maxillary Osteotomy for Severe Maxillary Protrusion. J Craniofac Surg. 24(1):80-83.

6. Margaliot Z, Chung KC.(2007). Systematic reviews: A primer for plastic surgery research. Plast Reconstr Surg. LWW.120(7):1834-41.

7. Okudaira M, Kawamoto T, Ono T, Moriyama K.(2008). Soft-tissue changes in association with anterior maxillary osteotomy: a pilot study. Oral Maxillofac Surg. 12(3):131-138.

8. Pan J, Hu J, Wang D.(1997).Soft tissue profile changes following surgical correction for Chinese adults with maxillary protrusion. West China J Stomatol.15(2):126-128.

9. Shawky MM, El-Ghareeb TI, Hameed Abu Hummos L a.(2012). Evaluation of the three-dimensional soft tissue changes after anterior segmental maxillary osteotomy. Int J Oral Maxillofac Surg. 41(6):718-726.

10. Sterne JAC, Hernán MA, Reeves BC, Savović J, Berkman ND, Viswanathan M, et al.(2016). ROBINS-I : a tool for assessing risk of bias in non-randomised studies of interventions ("Risk Of Bias In Non-randomised tool for evaluating risk of bias in.4-10.

11. Wassmund M.(1935). Lehrbuch der praktischen Chirurgie des Mundes und der Kiefer. H. Meusser.

12. Wunderer S.(1962). Die Prognathieoperation mittels frontal gestieltem Maxillafragment. Osterr Z Stomatol.59(98):102. 